\title{
Evaluation of Vaccination Rate and Risk of Infection Among Chronic Inflammatory Disease Patients Receiving Biologic Agents
}

\author{
다 Gülay Okay,1ำ Elmas Biberci Keskin²
}

'Department of Infectious Diseases and Clinical Microbiology, Bezmialem Vakif University Faculty of Medicine, İstanbul, Turkey 2Department of Gastroenterology, Bezmialem Vakif University Faculty of Medicine, İstanbul, Turkey

Submitted: 10.01.2020 Accepted: 22.04.2020

Correspondence: Gülay Okay, Bezmialem Vakıf Üniversitesi Tıp Fakültesi, Enfeksiyon Hastalıkları ve Klinik Mikrobiyoloji Anabilim Dalı, İstanbul Turkey

E-mail: gulay.okay@hotmail.com

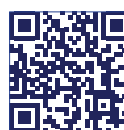

Keywords: Biologic therapy; infection; tumor necrosis factor; vaccination. Attribution-NonCommercial 4.0 International License.

\begin{abstract}
Objective: Biologic agents can provide effective control of disease activity in patients with chronic inflammatory disease (CID), however, they are associated with an increased risk of serious infection. The aim of this study was to investigate the risk and distribution of serious infection, the rate of vaccination, and the screening tests recommended in patients treated with biologic agents.
\end{abstract}

Methods: Patients with CID who were given biologic agent therapy were retrospectively evaluated. Hepatitis and tuberculosis (TB) screening tests, the vaccinations administered, risk factors for and the rate of serious infection were reviewed.

Results: Of the 320 patients included in the study, $58 \%$ were male and the mean age was 44.5 years ( \pm 12.2 years). The biologic agent used was infliximab in 108 patients $(33.8 \%)$, adalimumab in 115 (35.9\%), etanercept in 61 (19.1\%), ustekinumab in 19 (5.9\%), certolizumab in $9(2.8 \%)$, golimumab in $5(1.6 \%)$, and secukinumab in $3(0.9 \%)$. The hepatitis $\mathrm{B}$, pneumococcal, influenza, and hepatitis $A$ vaccination rate in patients with CID was $82.9 \%, 12.5 \%$, $11.6 \%$, and $4 \%$, respectively. The tuberculin skin test was preferred for $33.4 \%$ of the patients for TB screening, while the QuantiFERON-TB Gold test (Qiagen NV, Hilden, Germany) was used in $79 \%$. A total of 25 (7.8\%) cases of serious infection occurred, and the most common sites were the respiratory tract $(28 \%)$ and the urinary tract $(28 \%)$. Binary logistic regression analysis showed that the risk of infection was significantly higher in patients who had chronic obstructive pulmonary disease (COPD) and those who used azathioprine.

Conclusion: The most common sites of infection were the respiratory tract and the urinary tract, and the risk of infection was significantly higher in patients who had COPD and those who used azathioprine. The rate of vaccination was lower than has been recommended. Awareness of hepatitis $B$ and TB reactivation risk in patients treated with biologic agents was greater than awareness of the risk of other infections.

\section{INTRODUCTION}

The development of biologic agents has changed the management of many chronic inflammatory diseases (CIDs), including rheumatoid arthritis (RA), ankylosing spondylitis (AS), and psoriasis. ${ }^{[l]}$ Biological treatment is often necessary in mild and severe cases of CID to control symptoms, achieve clinical remission, and prevent longterm complications. Infliximab is a chimeric monoclonal antibody against tumor necrosis factor alpha (TNF- $\alpha$ ). Adalimumab and golimumab are fully human monoclonal antibodies against TNF- $\alpha$. Etanercept is a recombinant TNF- $\alpha$ receptor fusion protein. ${ }^{[2]}$ Ustekinumab and secukinumab are drugs that indirectly inhibit TNF- $\alpha$ by blocking interleukin (IL)- 12 and IL- 17.[3,4] While these biologic agents provide effective control of disease activity, they have strong immunosuppressive effects that can lead to serious complications.

Increased use of biologic agents to treat CID has been associated with an increase in the number of infections in recent years. Studies comparing patients who received anti-TNF- $\alpha$ treatment with healthy controls have indicated that the incidence of tuberculosis (TB) was approximately 14 times higher in the patient group. ${ }^{[5-7]}$ Pneumococcal pneumonia, influenza, and acute viral hepatitis infections have also been seen at higher rates in these patients. ${ }^{\left[{ }^{[8]}\right.} \mathrm{A}$ meta-analysis showed that patients receiving anti-TNF- $\alpha$ had double the risk of developing opportunistic infections. [9] Published guidelines recommend performing screening tests for TB and viral hepatitis $A$ and $B$, as well as influen$z a$, pneumococcal disease, and hepatitis $A$ and $B$ vaccines 
for all CID patients receiving biologic agents or expected to begin treatment with a biologic agent. ${ }^{[10-12]}$ Yet, despite these recommendations, the estimated vaccination rate is low among this patient group. ${ }^{[8,13]}$ The primary reason is that patients and doctors are not sufficiently aware of the importance of vaccination before initiating the use of biologic agents. ${ }^{[14,15]}$ At present, the data on vaccination status and the rate and risk of serious infection in patients using biologic agents are scarce in Turkey.

The aim of this study was to investigate the administration of screening tests and the rate of vaccination as recommended for patients who will be treated with a biologic agent. The risk, rate, and distribution of serious infection in these patients was also investigated.

\section{MATERIALS AND METHODS}

This study was conducted at the Bezmialem Foundation University School of Medicine Hospital in Istanbul, Turkey, and was approved by the Noninvasive Research Ethics Committee of the university on January 7, 2020 (no: 0I//0). Patients who were in outpatient follow-up with a diagnosis of CID and using a biologic agent between June 2018 and July 2019 were consecutively included in the study. The patients enrolled had a diagnosis of inflammatory bowel disease (IBD) (ulcerative colitis [UC] or Crohn's disease $[C D]$ ), rheumatologic diseases (RD) (RA or AS), or psoriasis.

Patients with a diagnosis of CID who were aged $>18$ years who were using a biologic agent for at least 6 months were enrolled in the study. The exclusion criteria were age of $<18$ years or insufficient data. The relevant guidelines were used to evaluate use of TB and viral hepatitis screening tests as well as vaccination rates in this retrospective, cross-sectional study. ${ }^{[10,1]]}$ The hepatitis $A$ antibody (HAAb), hepatitis $B$ surface antigen ( $\mathrm{HBsAg}$ ), hepatitis $B$ surface antibody (HBsAb), and hepatitis $B$ core antibody $(\mathrm{HBcAb})$ screening tests are recommended. The pneumococcal disease, influenza, and hepatitis $A$ and $B$ (non-immune individuals) vaccines are recommended. According to the guideline recommendations, TB prophylaxis should be initiated in patients who will be treated with a biologic agent if any of the following conditions are present: tuberculin skin test (TST) diameter $\geq 5 \mathrm{~mm}$, positive QuantiFERON-TB Gold test (Qiagen NV, Hilden, Germany) result, or findings showing latent $T B$ on a chest $X$-ray (calcified granulomas, pleural scar, apical densities, and/or hilar lymphadenopathy).

The risk factors for serious infection (and TB cases) as well as the frequency and distribution were also analyzed. Any infection that was life-threatening, required hospitalization, was treated with intravenous antibiotics, or caused significant morbidity, was considered a serious infection.

The data collected for analysis were age; sex; smoking history; comorbidities; type of CID; type of biologic agent and dates of use; additional immunosuppressive drug use; hepatitis A, hepatitis B, pneumococcus, and influenza vac- cination history and vaccination dates; viral hepatitis $A$ and $B$ screening tests; TB screening tests (chest $X$-ray, TST and/or QuantiFERON-TB test); and diagnosis and history of any serious infection.

Distribution of the data was analyzed using the Shapiro-Wilk test. A t-test was used in the comparison of 2 independent groups with normal distribution. The Fisher exact test, Pearson chi-squared, and the Fisher-Freeman-Halton tests were used to compare categorical data. The independent variables that were thought to have an effect on a dichotomous dependent variable were evaluated with backward logistic regression analysis. Descriptive statistics of the data were provided as frequency (percentage), median (interquartile range), and mean ( $\pm S D$ ). All of the statistical tests were analyzed and reported using IBM SPSS Statistics for Windows, Version 22.0 software (IBM Corp., Armonk, NY, USA) at a level of $\alpha=0.05$ and a confidence level of $95 \%$.

\section{RESULTS}

A total of 320 patients with CID who were using a biologic agent were included in the study. In the group, $58 \%$ of the patients were male and the mean age was 44.5 years $( \pm \mid 2.2$ years). There were $15 \mathrm{I}$ cases of psoriasis (47.2\%), 77 cases of CD (24.1\%), 38 cases of UC (II.8\%), 48 cases of AS (15\%), and 6 cases of RA (1.9\%). Twenty-two patients $(6.9 \%)$ had diabetes mellitus, 6 patients (I.3\%) had chronic obstructive pulmonary disease (COPD) and 6 patients had other comorbidities (Behçet's disease, chronic renal failure, HIV infection, congestive heart failure). There were 121 patients $(37.8 \%)$ who smoked. The biological agent used by the patients was infliximab in 108 cases $(33.8 \%)$, adalimumab in $115(35.9 \%)$, etanercept in $6 \mathrm{I}(19.1 \%)$, ustekinumab in $19(5.9 \%)$, certolizumab in $9(2.8 \%)$, golimumab in 5 ( $1.6 \%)$, and secukinumab in 3 $(0.9 \%)$. The mean duration of biologic agent use was 1420 days ( \pm 1015 days).

The rate of vaccination and TB screening is shown in Table I. Hepatitis B screening tests were performed in 100\% of the patients and prophylactic antiviral treatment was initiated in $6 \mathrm{HBsAg}$ positive patients. A hepatitis $B$ vaccine was administered to 190 (82.9\%) of 229 patients who had negative $\mathrm{HBsAg}$ and $\mathrm{HBs} \mathrm{Ab}$ results. There was no statistically significant difference in the percentage of patients receiving a hepatitis $B$ vaccine between the IBD, RD, and psoriasis groups $(p=0.166)$. An HAAb test was performed in only $4 \%$ of the patients $(n=13)$ and a hepatitis $A$ vaccine was not administered to any patient. The pneumococcal and influenza vaccination rate was $12.5 \%$ and $11.6 \%$, respectively. The pneumococcal vaccination percentage was significantly higher in the IBD group compared with the RD and psoriasis groups $(22.8 \%, 16.7 \%$, and $3.3 \%$, respectively, 18.8\%; $p<0.0001$ ). The percentage of influenza vaccination was significantly higher in the IBD group compared with the RD and psoriasis groups $(21.9 \%, 13 \%$ and $3.3 \%$ respectively, $18.8 \%$; $<<0.000 \mathrm{I}$ ). 
Table I. The rate of vaccination and tuberculosis screening test in patients with chronic inflammatory disease and using a biologic agent

\begin{tabular}{|c|c|c|c|c|c|}
\hline & Patients $(n=320)$ & IBD $(n=|| 2)$ & RD $(n=57)$ & $P D(n=151)$ & $\mathbf{p}$ \\
\hline \multicolumn{6}{|l|}{ Vaccine, n (\%) } \\
\hline Influenza & $37(11.6)$ & $25(21.9)$ & $7(13)$ & $5(3.3)$ & $<0.0001$ \\
\hline Pneumococcus & $40(12.5)$ & $26(22.8)$ & $9(16.7)$ & $5(3.3)$ & $<0.0001$ \\
\hline Hepatitis B* & $190(82.9)$ & $60(66.6)$ & $35(100)$ & $95(91.3)$ & NA \\
\hline \multicolumn{6}{|c|}{ Tuberculosis screening, $\mathrm{n}(\%)$} \\
\hline TST & $107(33.4)$ & $38(33.3)$ & $42(77.8)$ & $26(17.2)$ & $<0.0001$ \\
\hline QuantiFERON-TB & $252(79)$ & $92(80.7)$ & $19(35.2)$ & |4| (93.4) & $<0.0001$ \\
\hline Chest X-ray & $320(100)$ & $112(100)$ & $57(100)$ & $151(100)$ & NA \\
\hline
\end{tabular}

* In patients with negative hepatitis B surface antigen or hepatitis B surface antibody findings.

IBD: Inflammatory bowel disease; NA: Not applicable; PD: Psoriasis disease; RD: Rheumatologic disease; TST: Tuberculin skin test.

A TST and/or a QuantiFERON-TB test and a chest X-ray were performed in $100 \%$ of the patients to screen for TB. A TST was used in $33.4 \%$ of the patients and a QuantiFERON-TB test was administered in $79 \%$. In some cases, the TST and QuantiFERON-TB test were co-administered. In the study group, I 54 patients (48.I\%) who had a positive TST and/or QuantiFERON-TB test result received isoniazid prophylaxis (Table I).

A total of 25 cases (7.8\%) of serious infection were recorded. The distribution of infections is shown in Table 2. The most common sites of infection were the respiratory tract (28\%) (especially bacterial pneumonia) and the urinary tract (28\%). Cytomegalovirus infection (20\%), cellulitis (10\%), intra-abdominal infection (10\%), and herpes zoster infection (10\%) were also observed.

The variables analyzed as potential risk factors for the development of infection in the study group and the results of univariate analysis are presented in Table 3 . The rate of a comorbidity of COPD $(p=0.002)$, infliximab use $(p=0.007)$, diagnosis of IBD $(p=0.002)$, or azathioprine use as an additional immunosuppressive $(p=0.002)$ was significantly higher in the infection group. Independent risk factors, such as age, gender, type of biologic agent and duration of use, type of CID, presence of comorbidities, and use of other immunosuppressive drugs were included in the binary logistic regression model for the development

Table 2. Classification and frequency of infection

\begin{tabular}{lc}
\hline Type of infection & $\mathbf{n}$ (\% of infection/\% of total) \\
& $\mathbf{2 5}(\mathbf{1 0 0 / 7 . 8 )}$ \\
\hline Respiratory infection & $7(28 / 2.2)$ \\
$\quad$ Bacterial pneumonia & $5(20 / 1.6)$ \\
$\quad$ Tuberculosis & $2(10 / 0.6)$ \\
Cellulitis & $2(10 / 0.6)$ \\
Urinary & $7(28 / 2.2)$ \\
Intra-abdominal & $2(10 / 0.6)$ \\
Cytomegalovirus & $5(20 / 1.6)$ \\
Zona & $2(10 / 0.6)$ \\
\hline
\end{tabular}

of infection. Binary logistic regression analysis revealed that the risk of infection was significantly higher in patients who had COPD and those who used azathioprine (Table 4).

\section{DISCUSSION}

The hepatitis B, pneumococcal, influenza, and hepatitis A vaccination rate for patients with CID and using a biologic agent was determined to be $82.9 \%, 12.5 \%, 11.6 \%$, and $4 \%$, respectively. Variable immunization rates have been reported in previous studies, but most of the data have indicated low vaccinations rates consistent with our results. ${ }^{[8,16,17]}$ Melmed et al. ${ }^{[8]}$ reported the vaccination rate for tetanus, influenza, and pneumococcal disease to be $45 \%, 28 \%$, and $9 \%$, respectively. Another study found higher rates (Tdap: $67 \%$, influenza: $44 \%$, and pneumococcus: $24 \%$ ), however, they were still lower than optimal. ${ }^{[18]}$ Among the recommended vaccines, influenza, hepatitis $B$, and pneumococcus vaccines were requested for $55.4 \%, 16.1 \%$, and $19.6 \%$ of the patients, respectively, in a recent study published by $\mathrm{Al}-\mathrm{Omar}$ et al. ${ }^{[19]}$ These findings emphasize the need to raise awareness of both patients and doctors about vaccinations for patients using biologic agents.

In the current study, hepatitis B screening tests were performed for all of the patients and the vaccination rate was higher than that of all of the other vaccinations. A hepatitis A screening test was performed for only $4 \%$ of patients and no hepatitis $A$ vaccination was administered in the present study group. Similar results were obtained in a recent study. ${ }^{[18]}$ This suggests that awareness of the risk of hepatitis $B$ reactivation in patients with immune deficiency is high; however, awareness of fulminant hepatitis A infection in immunosuppressed patients remains very low. Karr et al. ${ }^{[20]}$ demonstrated the benefits of using a structured order panel to facilitate the request of the appropriate vaccinations. This approach may help to improve vaccination rates for CID patients.

A TST and/or QuantiFERON-TB test and a chest X-ray were performed for all of the study patients. Similarly, a previous study conducted in Turkey that analyzed patients 
Table 3. Patient characteristics by group

\begin{tabular}{|c|c|c|c|c|}
\hline Variable & $\begin{array}{c}\text { Total }(n=320) \\
n(\%)\end{array}$ & $\begin{array}{c}\text { Infection }(n=25) \\
n(\%)\end{array}$ & $\begin{array}{c}\text { No infection }(n=295) \\
n(\%)\end{array}$ & $\mathbf{p}$ \\
\hline Gender, male & $186(58.1)$ & $10(40)$ & $176(59.7)$ & 0.056 \\
\hline Age, years (mean $\pm S D)$ & $44.5( \pm 12.2)$ & $45.6( \pm 10.9)$ & $44.4( \pm 12.3)$ & 0.660 \\
\hline Duration of biologic agent use (days) (mean \pm SD) & $1420( \pm 1015)$ & $1547( \pm 1039)$ & $1409( \pm 1014)$ & 0.453 \\
\hline Smoker & $121(37.8)$ & $9(36)$ & $112(38)$ & 0.846 \\
\hline \multicolumn{5}{|l|}{ Comorbidities } \\
\hline DM & $22(6.9)$ & $3(12)$ & $19(6.4)$ & 0.397 \\
\hline COPD & $4(1.3)$ & $3(12)$ & $\mathrm{I}(0.3)$ & 0.002 \\
\hline Othera & $6(1.9)$ & $0(0)$ & $6(2)$ & NA \\
\hline \multicolumn{5}{|l|}{ Type of biologic agent } \\
\hline Infliximab & $108(33.8)$ & $15(60)$ & $93(31.5)$ & 0.007 \\
\hline Adalimumab & 115 (35.9) & $8(32)$ & $107(36.3)$ & 0.828 \\
\hline Etanercept & $61(19.1)$ & I (4) & $60(20)$ & 0.059 \\
\hline Ustekinumab & $19(5.9)$ & I (4) & $18(6.1)$ & 1 \\
\hline Certolizumab & $9(2.8)$ & $0(0)$ & $9(3.1)$ & NA \\
\hline Golimumab & $5(1.6)$ & $0(0)$ & $5(1.7)$ & NA \\
\hline Secukinumab & $3(0.9)$ & $0(0)$ & $5(1.7)$ & NA \\
\hline \multicolumn{5}{|l|}{ CID } \\
\hline IBD & $112(35)$ & $16(64)$ & $96(32.5)$ & 0.002 \\
\hline Rheumatologic disease & $57(17.8)$ & $2(8)$ & $55(18.6)$ & 0.276 \\
\hline Psoriasis & I5I (42.7) & $7(28)$ & I44 (49) & 0.044 \\
\hline \multicolumn{5}{|l|}{ Immunosuppressive drugs } \\
\hline Steroids & $18(5.6)$ & $2(8)$ & $16(5.4)$ & 0.641 \\
\hline Sulfasalazine & $43(13.4)$ & $7(28)$ & $36(16.2)$ & 0.059 \\
\hline Azathioprine & $45(14)$ & $10(40)$ & 35 (II.9) & 0.001 \\
\hline Methotrexate & $17(5.3)$ & $2(8)$ & $15(5)$ & 0.632 \\
\hline
\end{tabular}

Table 4. Logistic regression analysis of factors affecting development of infection

\begin{tabular}{lcccc}
\hline Variables & B & SE & OR & P \\
\hline Azathioprine use & 1.505 & 0.520 & 4.503 & 0.004 \\
Presence of COPD & 2.755 & 1.260 & 15.723 & 0.029 \\
\hline
\end{tabular}

${ }^{*} A$ p value of $<0.001$ was considered significant.

B: Regression coefficient; COPD: Chronic obstructive pulmonary disease; OR: Odds ratio; SE: Standard error.

with psoriasis noted that TB screening tests were performed for the majority of the patients. ${ }^{[5]}$ These results indicate that awareness of the TB reactivation risk is high for patients receiving biologic agents.

In our study, a TST was used in $33.4 \%$ of the patients and a QuantiFERON-TB Gold test was preferred as a TB screening test in $79 \%$. Other research has reported different rates. Ergun et al. ${ }^{[5]}$ found that a TST was performed in $80.8 \%$ of the patients and a QuantiFERON-TB test was performed in $16.8 \%$. The TST is a widely available and inexpensive test. Although the specificity of a TST is high in non-vaccinated populations (97\%), it is low and highly heterogeneous in bacillus Calmette-Guérin (BCG)-vacci- nated populations. ${ }^{[21,22]}$ Interferon-based tests are more appropriate to identify patients with latent TB who should be given prophylactic treatment because they eliminate cross-reactivity with BCG and non-TB mycobacteria. Interferon-based tests have replaced the use of a TST they better differentiate latent TB from vaccine reactivity. ${ }^{[23]}$

In the current study, 25 cases $(7.8 \%)$ of serious infection were associated with biologic agent treatment. The most common sites of infection were the respiratory tract $(28 \%)$ and the urinary tract $(28 \%)$. In recent studies, the most frequent serious infection in users of biologic agents was found to be a respiratory infection, which is consistent with our findings. ${ }^{[24,25]}$ In another study, the rate of infection in patients receiving anti-TNF- $\alpha$ was $6 \%$, and the most common site was the intra-abdominal region. ${ }^{[26]} \mathrm{TB}$ was the second most common infection in that study.

Among our patients, 2 developed a TB infection (2/320, $0.6 \%$ ). One developed TB at the sixth month of biologic agent treatment, while the other developed TB in the third year. Ergun et al. ${ }^{[5]}$ studied patients who were receiving anti-TNF- $\alpha$, and found that the TB reactivation rate was $1.08 \%$, which is consistent with our results. The role of TNF- $\alpha$ in the immune response against Mycobacterium 
tuberculosis is unclear. However, in vitro studies have suggested that TNF- $\alpha$ plays an important role in granuloma formation, which limits TB bacillus proliferation. ${ }^{[27]}$ The use of anti-TNF- $\alpha$ agents can lead to the dissolution of granulomas, the release of live mycobacteria, and the reactivation of the disease. This may explain the high incidence of TB seen in patients using anti TNF- $\alpha$ agents.

Binary logistic regression analysis revealed that the risk of infection was significantly higher in patients with COPD and in patients who were using azathioprine in our study. Several studies have reported that comorbidities of chronic lung disease are predictive of serious infection. ${ }^{[25,28]}$ In a study conducted with RA patients, logistic regression models indicated that the patients who experienced a serious infection were significantly more likely to have COPD and to have initiated biologic agent treatment before 2010. ${ }^{[24]}$ Various meta-analyses have compared the risk of serious infection with several biologic agents. It was concluded that some biologic agents may cause an increased risk of serious infection more than others. ${ }^{[29,30]}$ However, other studies have not found a significant relationship between biologic treatments and the risk of serious infection. ${ }^{31,32]}$ We agree with the idea that the risk of serious infection depends on various factors, including demographic characteristics, comorbidities, use of other immunosuppressive drugs, and other patient-specific risk factors, in addition to the use of biologic agents. ${ }^{[3]}$

Limitations of this research include the relatively small study group drawn from a single center. Multicenter studies with more patients are needed to obtain more precise results. In addition, this study was conducted retrospectively. The absence of a control group of patients who did not use a biologic agent is another limitation of our study.

\section{CONCLUSION}

The rate of immunization for CID patients using a biologic agent was lower than recommended. Hepatitis B and TB screening tests were performed for all of the patients, and the hepatitis $B$ vaccination rate was the highest. We concluded that awareness of the risk of hepatitis B and TB reactivation in patients receiving a biologic agent was greater than that of other infections. The most common sites of infection were the respiratory tract and the urinary tract, and the risk of infection was significantly higher in patients who had COPD and who used azathioprine. These results may provide valuable information for doctors who monitor patients using a biologic agent and raise awareness of the importance of timely vaccination of these patients and monitoring for serious infection. Structured reminders for vaccinations and education for both patients and physicians may prove beneficial in improving immunization rates among these patients.

Ethics Committee Approval

Approved by the Bezmialem Foundation University School of Medicine Hospital Ethics Committee (January 7, 2020, No: 0l/10).

Peer-review

Internally peer-reviewed.

Authorship Contributions

Concept: G.O.; Design: G.O., E.B.K.; Supervision: G.O.; Fundings: G.O., E.B.K.; Materials: G.O., E.B.K.; Data: G.O., E.B.K.; Analysis: G.O., E.B.K.; Literature search: G.O., E.B.K.; Writing: G.O.; Critical revision: G.O., E.B.K.

Conflict of Interest

None declared.

\section{REFERENCES}

1. Quartuccio L, Zabotti A, Del Zotto S, Zanier L, De Vita S, Valent F. Risk of serious infection among patients receiving biologics for chronic inflammatory diseases: usefulness of administrative data. J Adv Res 2018;15:87-93. [CrossRef]

2. Pecoraro V, De Santis E, Melegari A, Trenti T. The impact of immunogenicity of TNFa inhibitors in autoimmune inflammatory disease. A systematic review and meta-analysis. Autoimmun Rev 2017;16:564-75. [CrossRef]

3. Krulig E, Gordon KB. Ustekinumab: an evidence-based review of its effectiveness in the treatment of psoriasis. Core Evid 2010;5:11-22.

4. Reszke R, Szepietowski JC. Secukinumab in the treatment of psoriasis: an update. Immunotherapy 2017;9:229-38. [CrossRef]

5. Ergun T, Seckin D, Baskan Bulbul E, Onsun N, Ozgen Z, Unalan P, et al. The risk of tuberculosis in patients with psoriasis treated with anti-tumor necrosis factor agents. Int J Dermatol 2015;54:594-9.

6. Dixon WG, Hyrich KL, Watson KD, Lunt M, Galloway J, Ustianowski A; B S R B R Control Centre Consortium, Symmons DP; BSR Biologics Register. Drug-specific risk of tuberculosis in patients with rheumatoid arthritis treated with anti-TNF therapy: results from the British Society for Rheumatology Biologics Register (BSRBR). Ann Rheum Dis 2010;69:522-8. [CrossRef]

7. Tubach F, Salmon D, Ravaud P, Allanore Y, Goupille P, Bréban M, et al; Research Axed on Tolerance of Biotherapies Group. Risk of tuberculosis is higher with anti-tumor necrosis factor monoclonal antibody therapy than with soluble tumor necrosis factor receptor therapy: the three-year prospective French research axed on tolerance of biotherapies registry. Arthritis Rheum 2009;60:1884-94. [CrossRef]

8. Melmed GY, Ippoliti AF, Papadakis KA, Tran TT, Birt JL, Lee SK, et al. Patients with inflammatory bowel disease are at risk for vaccine-preventable illnesses. Am J Gastroenterol 2006;101:1834-40.

9. Ford AC, Peyrin-Biroulet L. Opportunistic infections with anti-tumor necrosis factor-a therapy in inflammatory bowel disease: meta-analysis of randomized controlled trials. Am J Gastroenterol 2013;108:1268-76. [CrossRef]

10. Farraye FA, Melmed GY, Lichtenstein GR, Kane SV. Acg clinical guideline: preventive care in inflammatory bowel disease. Am J Gastroenterol 2017;112:241-58. [CrossRef]

11. CDC: Recommended immunization schedule for adults aged 19 years or older, United States, 2018. Available at: https://www.cdc. gov/vaccines/schedules/hcp/imz/adult.html. Accessed Feb 15, 2021.

12. Rubin LG, Levin MJ, Ljungman P, Davies EG, Avery R, Tomblyn M, et al; Infectious Diseases Society of America. 2013 IDSA clinical practice guideline for vaccination of the immunocompromised host. Clin Infect Dis 2014;58:309-18 [CrossRef]

13. Parker S, Chambers White L, Spangler C, Rosenblum J, Sweeney S, Homan E, et al. A quality improvement project significantly increased 
the vaccination rate for immunosuppressed patients with IBD. Inflamm Bowel Dis 2013;19:1809-14.

14. Jung YS, Park JH, Kim HJ, Cho YK, Sohn CI, Jeon WK, et al. Insufficient knowledge of Korean gastroenterologists regarding the vaccination of patients with inflammatory bowel disease. Gut Liver 2014;8:242-7. [CrossRef]

15. Gupta A, Macrae FA, Gibson PR. Vaccination and screening for infections in patients with inflammatory bowel disease: a survey of Australian gastroenterologists. Intern Med J 2011;41:462-7. [CrossRef]

16. Malhi G, Rumman A, Thanabalan R, Croitoru K, Silverberg MS, Hillary Steinhart A, et al. Vaccination in inflammatory bowel disease patients: attitudes, knowledge, and uptake. J Crohns Colitis 2015;9:439-44. [CrossRef]

17. Loubet P, Verger P, Abitbol V, Peyrin-Biroulet L, Launay O. Pneumococcal and influenza vaccine uptake in adults with inflammatory bowel disease in France: results from a web-based study. Dig Liver Dis 2018;50:563-7. [CrossRef]

18. Pham HV, Hasan I, Udaltsova N, Pham K, Abramson O, Armstrong $\mathrm{MA}$, et al. Rates and predictors of vaccinations among inflammatory bowel disease patients receiving anti-tumor necrosis factor agents. Dig Dis Sci 2018;63:209-17. [CrossRef]

19. Al-Omar HA, Sherif HM, Mayet AY. Vaccination status of patients using anti-TNF therapy and the physicians' behavior shaping the phenomenon: mixed-methods approach. PLoS One 2019;14:e0223594. [CrossRef]

20. Karr JR, Lu JJ, Smith RB, Thomas AC. Using computerized physician order entry to ensure appropriate vaccination of patients with inflammatory bowel disease. Ochsner J 2016;16:90-5.

21. Laffitte E, Janssens JP, Roux-Lombard P, Thielen AM, Barde C, Marazza G, et al. Tuberculosis screening in patients with psoriasis before antitumour necrosis factor therapy: comparison of an interferon-gamma release assay vs, tuberculin skin test. Br J Dermatol 2009;161:797-800. [CrossRef]

22. Mariette X, Baron G, Tubach F, Lioté F, Combe B, Miceli-Richard $\mathrm{C}$, et al. Influence of replacing tuberculin skin test with ex vivo interferon $\mathrm{g}$ release assays on decision to administer prophylactic antituberculosis antibiotics before anti-TNF therapy. Ann Rheum Dis 2012;71:1783-90. [CrossRef]

23. Mrozek N, Pereira B, Soubrier M, Gourdon F, Laurichesse H. Screening of tuberculosis before biologics. Med Mal Infect 2012;42:1-4
24. Ichinose K, Shimizu T, Umeda M, Fukui S, Nishino A, Koga T, et al. Frequency of hospitalized infections is reduced in rheumatoid arthritis patients who received biological and targeted synthetic disease-modifying antirheumatic drugs after 2010. J Immunol Res 2018;2018:6259010. [CrossRef]

25. Mori S, Yoshitama T, Hidaka T, Sakai F, Hasegawa M, Hashiba Y, et al. Comparative risk of hospitalized infection between biological agents in rheumatoid arthritis patients: a multicenter retrospective cohort study in Japan. PLoS One 2017;12:e0179179. [CrossRef]

26. Yoo IK, Choung RS, Hyun JJ, Kim SY, Jung SW, Koo JS, et al. Incidences of serious infections and tuberculosis among patients receiving anti-tumor necrosis factor-a therapy. Yonsei Med J 2014;55:442-8.

27. Clay H, Volkman HE, Ramakrishnan L. Tumor necrosis factor signaling mediates resistance to mycobacteria by inhibiting bacterial growth and macrophage death. Immunity 2008;29:283-94. [CrossRef]

28. Hashimoto A, Suto S, Horie K, Fukuda H, Nogi S, Iwata K, et al. Incidence and risk factors for infections requiring hospitalization, including pneumocystis pneumonia, in Japanese patients with rheumatoid arthritis. Int J Rheumatol 2017;2017:6730812. [CrossRef]

29. Michaud TL, Rho YH, Shamliyan T, Kuntz KM, Choi HK. The comparative safety of tumor necrosis factor inhibitors in rheumatoid arthritis: a meta-analysis update of 44 trials. Am J Med 2014;127:1208-32. [CrossRef]

30. Singh JA, Wells GA, Christensen R, Tanjong Ghogomu E, Maxwell L, Macdonald JK, et al. Adverse effects of biologics: a network meta-analysis and Cochrane overview. Cochrane Database Syst Rev 2011;2011:CD008794. [CrossRef]

31. Thompson AE, Rieder SW, Pope JE. Tumor necrosis factor therapy and the risk of serious infection and malignancy in patients with early rheumatoid arthritis: a meta-analysis of randomized controlled trials. Arthritis Rheum 2011;63:1479-85. [CrossRef]

32. Campbell L, Chen C, Bhagat SS, Parker RA, Östör AJ. Risk of adverse events including serious infections in rheumatoid arthritis patients treated with tocilizumab: a systematic literature review and meta-analysis of randomized controlled trials. Rheumatology (Oxford) 2011;50:552-62. [CrossRef]

33. Curtis JR, Yang S, Patkar NM, Chen L, Singh JA, Cannon GW, et al. Risk of hospitalized bacterial infections associated with biologic treatment among US veterans with rheumatoid arthritis. Arthritis Care Res (Hoboken) 2014;66:990-7. [CrossRef]

\section{Biyolojik Ajan Kullanan Kronik Enflamatuar Hastalılığı Olan Hastalarda Aşılama Oranlarının ve Enfeksiyon Riskinin Değerlendirilmesi}

Amaç: Biyolojik ajanlar, kronik enflamatuvar hastalığı $(\mathrm{KEH})$ olan hastalarda hastalık aktivitesinin etkili kontrolünü sağlar. Bununla birlikte, ciddi enfeksiyon riski artışı ile ilişkilidirler. Bu çalışmanın amacı, biyolojik ajan kullanan hastalarda ciddi enfeksiyonların dağıımı ve riskini, bu hastalardaki önerilen tarama testleri ve aşılama oranlarını araştırmaktır.

Gereç ve Yöntem: Biyolojik ajan alan KEH'li hastaları geriye dönük olarak değerlendirdik; hepatit ve tüberküloz (TB) tarama testlerini ve önerilen aşıları, ciddi enfeksiyon oranlarını ve risk faktörlerini gözden geçirdik.

Bulgular: Çalışmaya dahil edilen 320 hastanın \%58'i erkek ve ortalama yaş 44.5 ( \pm I2.2) idi. Hastaların kullandığı biyolojik ajanların dağıımı; Infliksimab 108 (\%33.8), Adalimumab II5 (\%35.9), Etanercept 6 I (\% |9.I), Ustekinumab 19 (\%5.9), Sertolizumab 9 (\%2.8), Golimumab 5 (\%।.6) ve Sekukinumab 3 (\%0.9). KEH'li hastalarda hepatit B, pnömokok, influenza ve hepatit A aşılama oranları sırasıyla \%82.9, \% I2.5, \% I I.6 ve \%4 bulundu. TB tarama testi olarak hastaların \%33.4'ünde tüberküloz cilt testi, \%79'unda QuantiFERON-TB Gold testi tercih edildi. Toplam 25 (\%7.8) ciddi enfeksiyon olgusu meydana geldi ve en sık görülen enfeksiyon bölgesi solunum yolu (\%28) ve idrar yolu (\%28) olarak bulundu. İkili lojistik regresyon analizi, kronik obstrüktif akciğer hastalığı (KOAH) olan ve azatiyoprin kullanan hastalarda enfeksiyon riskinin anlamlı derecede daha yüksek olduğunu gösterdi.

Sonuç: En sık görülen enfeksiyon bölgeleri solunum yolu ve idrar yolu idi ve KOAH olan ve azatiyoprin kullanan hastalarda enfeksiyon riski anlamlı derecede yüksekti. KEH hastaları için aşılama oranları önerilenden düşüktü. Biyolojik ajan kullanan hastalarda hepatit B ve TB reaktivasyon riski farkındalığı, diğer enfeksiyonlara göre daha yüksek olduğu sonucuna varıldı.

Anahtar Sözcükler: Aşlama; biyolojik tedavi; enfeksiyon; tümör nekroz faktörü. 